Journal of Critical Race Inquiry

Volume 3, Number 1 (2016) pp. 4-5

\title{
Curatorial Statement: Salt. Washing. Beuys. Fat. Royalty. Copper. Canadian Club. John. Locked. Bear. Drum. Circle.
}

\author{
Performance by Peter Morin, 22 March 2015 \\ Talkin' Back to Johnny Mac performance series
}

\author{
Erin Sutherland \\ American Indian and Indigenous Studies Program, Michigan State University
}

During the $200^{\text {th }}$ birthday celebrations for Sir John A. Macdonald, communities both locally in Kingston and across Canada attempted to create critical interventions. The performance series Talkin'Back to Johnny Mac created a platform for discussing Macdonald as a symbol of Canadian nationalism that promotes the selective remembering of Canadian history. The series aimed to foster critical investigations of "capital ' $\mathrm{N}$ "' nationalism and its strengthening though the iconization of historical figures like Macdonald. Specifically, the series looked to examine Macdonald as a figure who laid the foundations for Canada's current colonial culture by drawing connections between Macdonald's time, his colonial policies, and our historical present. These discussions formed in Kingston around five new performance works produced by internationally regarded interdisciplinary artists between 11 January and 30 April 2015. Artists Leah Decter, David Garneau (Métis), Tanya Lukin-Linklater (Alutiiq), Peter Morin (Tahltan), and Adrian A. Stimson (Blackfoot) produced five distinct and innovative performances. Each site-specific performance critiqued the birthday celebrations of John A. Macdonald and the foundation narratives in which he is a central figure. By speaking back to John A. Macdonald in unique ways, these artistic interventions made visible non-dominant discourses of Canada. 
The image included on the cover of this journal is from Tahltan artist Peter Morin's performance, Salt. Washing. Beuys. Fat. Royalty. Copper. Canadian Club. John. Locked. Bear. Drum. Circle. The image portrays Morin being suffocated by a rye-soaked British flag while kneeling in front of the Macdonald statue in Kingston. This action, one of many taken by Morin during the performance, evoked the continuing erasure of Indigenous cultures in Canada and the stifling of Indigenous presence by assimilative forces. Kneeling in front of Macdonald, Morin connected ongoing Indigenous suffering to the Prime Minister and, more broadly, to the construction of Canada as a British colonial nation. Despite the pain of the action pictured here, through further performative actions Morin repurposed the statue into a pirate broadcasting station. Morin invited audience members to hold copper pipes to the statue's base. He then spoke and sang into the pipes, allowing his voice to be brought up through the pipes and through the statue into the air and across the universe. Morin's words and song communicated resilience and sovereignty to Indigenous peoples across Turtle Island and to the ancestors. In this action, and throughout his performance, Morin briefly removed the power of the colonial symbols of the statue and Prime Minister, and instead used them for his own voice. Through this repurposing of colonial iconography, Morin truly spoke back to John A Macdonald.

Peter Morin is a Tahltan Nation artist, curator and writer currently based in Brandon, Manitoba. Morin studied art at Emily Carr Institute and completed his MFA at UBC Okanagan in 2011. In both his artistic practice and his curatorial work, Morin explores issues of de-colonization and indigenous identity and language. Morin's group and solo exhibitions and live events include 7 Suits for 7 Days of Colonialism, and A return to the place where God outstretched his hand (2007); 12 Making Objects AKA First Nations DADA (12 Indigenous Interventions) (2009); and Peter Morin's Museum (2011). Morin has curated exhibitions at the Museum of Anthropology, Western Front, The Burnaby Art Gallery and Grunt Gallery among others. In 2010 the artist was awarded the British Columbia Creative Achievement Award for First Nations' Art.

Erin Sutherland is a Pre-Doctoral Fellow in the American Indian and Indigenous Studies Program at Michigan State University and a $\mathrm{PhD}$ candidate in the Cultural Studies Graduate Program at Queen's University. Sutherland is of Métis descent and her research and curatorial work focuses on Indigenous curatorial methodologies and performance art. 